\title{
Financial-Economic Profile of Firms in the European Publishing Industry
}

\author{
ANa Bedate Centeno a , José Ángel SANZ LARA a , MARIANo DURÁNTEZ \\ VALLEJO $^{\text {a }}$ \\ a Universidad de Valladolid, Facultad de Comercio, Plaza del Campus Universitario, 1, 47011 \\ Valladolid,España.E-mail: ana@emp.uva.es, angel@emp.uva.es, mariano@emp.uva.es
}

\begin{abstract}
In the field of cultural industries, the publishing sector is one of the most important areas due to its huge turnover, the number of jobs it generates, and its contribution to GDP, amongst other factors. This sector has been the focus of numerous studies for many years, from a variety of standpoints such as: supply and demand, global markets, intellectual property rights, digital formats, and so on.

The present study seeks to gain an understanding of this sector from the viewpoint of the financial situation of the firms involved, exploring such aspects as size, specialization, and financial economic profile. The goal is to gain further insights into the sector, describe it and to define a classification of firms that display similar financialeconomic features, by applying multivariate size-reduction techniques in order to pinpoint the key factors in their financial structure that will enable us to form homogeneous clusters of firms.
\end{abstract}

Keywords: Cultural Industries, Publishing Sector, Financial Data, Cluster Analysis.

\section{Perfil económico-financiero de las empresas de la industria editorial europea}

\section{RESUMEN}

En el ámbito de las industrias culturales, el sector editorial es una de las áreas más importantes debido a su gran volumen de negocio, el número de empleos que genera, y su contribución al PIB, entre otros factores. Este sector ha sido objeto de numerosos estudios durante muchos años, a partir de una variedad de puntos de vista tales como: la oferta y la demanda, los mercados globales, los derechos de propiedad intelectual, los formatos digitales, etc.

El presente estudio tiene por objeto analizar este sector desde el punto de vista de la situación financiera de las empresas implicadas, explorando aspectos tales como el tamaño, la especialización y el perfil económico financiero. El objetivo es obtener un mejor conocimiento del sector, describirlo y definir una clasificación de las empresas con características económico-financieras similares, mediante la utilización de técnicas multivariantes de reducción de dimensiones para determinar los factores clave de su estructura financiera que nos permita formar grupos homogéneos de empresas.

Palabras clave: Industrias Culturales, Sector Editorial, Datos Financieros, Análisis Cluster.

JEL Classification: C38, G00, Z11

Artículo recibido en septiembre de 2016 y aceptado en marzo de 2017

Artículo disponible en versión electrónica en la página www.revista-eea.net, ref. ə-35205 


\section{INTRODUCTION}

In any of its formats, a book is a means of spreading knowledge and conveying literary creation which proves key in the educational process and which for many is an important source of leisure and personal enrichment. The publishing sector is thus an area of great importance in the field of cultural industries, since it is the oldest and also has the largest volume of sales. Its traditional market is enormous in addition to which it evidences vast potential given the ever-increasing progress of new technologies and the advantages afforded by a global market.

In its annual 2013 report, the International Publishers Association (IPA) stated that total turnover in the publishing sector for 2012 amounted to some 114 thousand million Euros worldwide, a figure which is highly concentrated in a small number of countries. The twenty countries with the largest book sales account for $84 \%$ of the market and, more specifically, $60 \%$ of global spending is shared amongst just six countries: the United States (26\%), China (12\%), Germany (8\%), Japan (7\%), France (4\%) and the United Kingdom (3\%). In this map of the publishing world, in addition to the aforementioned countries, two regions stand out for their importance: the European Union with 33\% of world sales, and the BRIC $^{1}$ countries with $18 \%$, where China is one of the main powerhouses.

Nowadays, it is impossible to talk of the publishing sector without mentioning electronic books, with the early portable digital readers having first come on to the market in the late 90s. In 2000, the publication of a book exclusively in digital format by the writer Stephen King heralded a landmark in marketing potential $^{2}$, and digital books are currently gaining ground in markets, although not to the same extent in all countries. Anglo-American markets lead the way in this digital subsector of the publishing market with the highest turnover ${ }^{3}: 12.5 \%$ in the United Kingdom, 15\% in Canada and 20\% in the United States. In its early days, the electronic book market in the US represented a tiny fraction of overall turnover, although the trend began to change after 2009 when the digital business already stood at $3.17 \%$ of total sales, before reaching its present levels. The factors behind this rapid growth have mainly been related to language, the level of development in these countries, which has allowed the technology related to digital books to be acquired rapidly, and the marketing strategies

\footnotetext{
${ }^{1}$ Brazil, Russia, India and China, vast countries with huge populations, which in recent years are experiencing high economic growth rates and involvement in world trade.

2 Stephen King launched his novel "Riding Bullet" in digital format at a cost of $2.5 \$$ and sold 500,000 copies in 48 hours. It could only be read on computer.

3 Data taken from Clee (2013) for UK; BookNet Canada (2013) for Canada and from the BookStats Highlights (2013) commissioned by the Association of American Publishers (AAP) and by Book Industry Study Group (BISG) for USA.
} 
aimed at increasing e-book sales among children and teenagers. In Europe ${ }^{4}$, books in digital format have gained ground in markets although far more slowly, with figures of 5.4\% in Germany, 4\% in the Netherlands, 3\% in France and Spain, and 1.8\% in Italy in 2012. In addition to the damaging effect which the crisis has had on consumer spending, one further reason behind such slow growth in recent years is the taxation levied in the European Union on ecommerce ${ }^{5}$. ICT is here to stay in the world of education and the future of culture and in particular the book is closely linked to technological progress and is unstoppable, such that in the long run this sector is likely to undergo enormous growth.

Faced with this situation, the publishing sector is gradually adapting to the changes in people's consumer habits, and is innovating both in terms of production and marketing models. Content remains the key factor for consumers, although now they can access the media and entertainment anywhere and at any time. A substantial drop is currently being observed in the amount of time people devote to watching television as a result of using Internet, meaning that advertising and sales through this means of communication are becoming increasingly important and gaining ground to the detriment of conventional models ${ }^{6}$. For these reasons, in addition to focusing their efforts on production, publishers also need to pay particular attention to other aspects which are now key such as setting prices and controlling distribution.

Firms involved in this sector have enormous opportunities thanks to technological innovation and the development of communications. Yet, they also face a struggle to strike the right balance in the market, where they are confronted with three-fold competition from electronics firms manufacturing reading devices, telecommunications firms supplying Internet connections, and various multinational firms operating in Internet, such as Amazon, Apple, Barnes \& Noble, Google and Kobo, etc. None of these are devoted specifically to publishing and yet they are the ones who are reaping the greatest benefit from the profits to come out of the sector due to their rapid growth and dominant market position. Meanwhile, the legislative framework of the various authorities is developing extremely slowly in the fight against piracy and unfair competition ${ }^{7}$.

\footnotetext{
${ }^{4}$ Data taken from Observatorio de la Lectura y el Libro (2013).

${ }^{5}$ According to Directive 2006/112/EC, of 28 November 2006, VAT levied on digital books ranges between $18 \%$ and $21 \%$.

${ }^{6}$ According to forecasts published by PricewaterhouseCoopers (2013), by 2017 digital media are expected to represent $37 \%$ of advertising revenue compared to $26 \%$ in 2012 , and physical purchases will only account for $53 \%$ of total consumer spending.

${ }^{7}$ Work is being done on regulating the digital book market with regard to taxation and the removal of restrictions imposed by the device or digital book distributor.
} 
The present article pursues two clearly differing goals. Firstly, we aim to gain a deeper insight into the European publishing sector by describing its main features such as the most successful categories, forms of distribution, number of publications, turnover, translations, exports, etc., in the five leading European powers: Germany, France, the UK, Spain and Italy. The study provides a comparative analysis of the market features in these countries by merging multiple data sources. Secondly, an empirical analysis is carried out of the available financial ratios of the publishing firms with the largest turnover in the EU-28, in order to classify them in terms of their financial-economic performance. The study is innovative since, for the publishing sector, to the best of our knowledge there are no other applications which explore this particular aspect of firms.

The article is structured in four sections. Together with this introduction, which focuses on evidencing the importance of the publishing sector at a global scale, the second section addresses the first objective, namely to describe the publishing industry in Europe. The third section deals with the empirical application summing up the information concerning the financial ratios so as to then classify firms. Finally, the conclusions are presented.

\section{THE PUBLISHING SECTOR IN EUROPE}

Cultural industries in Europe are a key business sector, ahead of others such as energy or agriculture. According to data in the 2010 Tera Consultants report, the creative industries contributed $4.5 \%$ to gross added value in what was at the time a 27 -country Europe, 6.5\% in the UK, $4.9 \%$ in France, $4.2 \%$ in Germany, $3.8 \%$ in Italy, and $3.6 \%$ in Spain. As regards employment, figures are similar to those above, since they account for 3.8\% in the EU-27, 5.4\% in the UK, 3.7\% in France, $4.1 \%$ in Germany, 3.6\% in Italy, and 3.5\% in Spain.

The publishing industry is the sector generating the greatest wealth within the cultural industries. According to data from the Federation of European Publishers (2012), total revenue obtained in 2012 by book publishers in the 28 countries of the European Union amounted to 22.5 thousand million Euros, and gave 130,000 full-time jobs. Leaving aside a slight drop in these figures compared to the previous year as a result of the economic crisis, the main markets in terms of turnover were Germany, the United Kingdom, France, Spain, and Italy, who are five of the world leaders in the publishing sector. Table 1 shows the main result of a comparative study dealing with the publishing industry in these five countries for 2011, and which is now commented on.

On the demand side ${ }^{8}$, the cultural habits of Europeans and, in particular,

\footnotetext{
${ }^{8}$ Analysis of the demand for books in Spain may be consulted in Palma et al. (2009) and Villarroya and Escardíbul (2010).
} 
reading habits, play a key role. Age and consumers' cultural and economic level are the main factors determining cultural participation, with level of education being the most important in the case of reading according to the Special Eurobarometer 399 (European Commission, 2013). This latter report shows that it is the northern European countries that most frequently engage in cultural activities. Sweden particularly stands out as having the highest participation rates in all facets of culture, with $90 \%$ of those surveyed for this report having read at least one book over the last year. This figure is 68\% across the European Union as a whole, and is at its lowest in Portugal (40\%). Among the European countries with the strongest publishing industry, the UK (80\%), Germany (79\%) and France (73\%) are above the average, with Spain (60\%) and Italy (56\%) below. The reasons why people do not read are mainly lack of time amongst those aged between 25 and 39, and lack of interest amongst those who left school before the age of 15 (European Commission, 2013).

Obviously, percentages of book purchases are slightly below percentages of readers. We only have data available for Spain, where 55.4\% of those surveyed purchased at least one book in 2011 (Conecta, 2013) and France, where the figure was 54\% of those over 15 years of age who purchased books 2012 (Lacroix, 2012, pp 139-153). The most successful kind of books on the market in most of the countries analysed were: literature, children and young adult's fiction. Together with production, distribution is key to this particular sector, with bookstores and bookstore chains or specialised cultural stores tending to lead the way, followed by large department stores and supermarkets. Yet, purchasing habits are not the same in all countries. For instance, in the UK Internet sales already top the list, outstripping bookstores, and in Germany second behind bookstores are catalogue sales, which are extremely popular in Germany, and direct sales from publishing companies.

In many European countries, book prices are regulated through laws known as Fixed Price Laws ${ }^{9}$. These include Austria, Denmark, Germany, Greece, Hungary, Italy, the Netherlands, Portugal, France, and Spain. These Fixed Price Laws establish that publishers can set the price of a book, making it the same in all kind of outlets, allowing for a maximum discount of around 5\%, except for book fairs and public libraries. This law is based on the notion that a book is a cultural good and that therefore production of and access to it should be protected, this running in line with the official stance of the European Parliament. By contrast, there are also countries which adopt a free pricing system such as Belgium, Finland, Ireland, Luxembourg, the UK, Sweden, and Switzerland, where there is opposition to any protectionist measures in the cultural sector. By

\footnotetext{
${ }^{9}$ By way of an example, we can cite the Loi 81/766, of 10 August 1981 in France, and Ley 10/2007, of 22 June 2007 on reading, books, and libraries in Spain, as well as Decreto-Lei 176/96, of 21 September 1996 in Portugal.
} 
way of an illustration, the average price of a printed book is $18 €$ in Italy, $14.45 €$ in Germany, and $13.87 €$ in Spain.

The VAT applicable to books is a thorny issue in most countries, since VAT in the European Union is not the same for printed books as for digital books. In line with EU Directive 2006/112/EC, European legislation considers electronic books to be a digital download service, such that it is taxed at between $18 \%$ and $21 \%$, whereas the printed book tends to benefit from reduced VAT in most countries. In 2012, France decided not to apply this rule and cut VAT on digital books to $7 \%$ while Luxembourg set it at 3\%. As a result, Amazon registered in Luxembourg and, taking advantage of said country's tax law, currently holds a monopoly on the sector in Europe. The European Union is at present studying fresh digital book market regulation to make firms charge VAT in the purchaser's country of residence and not in the distributor's.

Exports and translation licences in the sector are proving another key factor to resisting the current crisis and the countries benefitting most in this sense are those whose language affords them the greatest possibilities. Export figures are closely related to the size of the publishing market in each of the countries. As regards translations into other languages, English, Spanish and Chinese stand head and shoulders above the rest. The percentage of works translated in the domestic market of the five leading European countries ranges from 3\% in the UK to 22\% in Spain, with English being the main source language for translation.

The business sector in these five countries also varies enormously, ranging between approximately 1000 and 3000 firms, with turnover levels at market prices of over 1,800 million Euros, with Germany leading the way followed by the UK. In 2011, over 54,000 book titles were produced in each of the five countries, with the UK occupying top spot with 170,267, followed by Spain with 104,724 , with $19.8 \%$ of these being produced in digital format. The main feature worth highlighting is that publishing sector firms are highly concentrated. In other words, there is a small number that dominate the market, with the remainder being spread over a large number of SMEs. For example, in Germany the large firms with a turnover of above 50 million Euros take almost $70 \%$ of the total revenue in the sector. In Spain, $4 \%$ of the largest firms account for over $64 \%$ of the business. In the UK, $12.6 \%$ of firms reported a turnover of above one million pounds whereas for over half of the firms this figure was below 100,000 pounds a year. In the French book distribution sector, the five main companies had a market share of over $50 \%$.

The situation of firms in this sector, which in recent years have been hit by a global crisis coupled with a difficult and per force rapid adaptation to technological changes as well as new purchase and consumption habits, may be reflected in the information from their financial ratios. For this reason, after describing the European publishing industry, the following paragraph posits an 


\section{empirical study of European publishing firms from the financial-economic standpoint.}

Table 1

Comparative study of the five European powers in the publishing sector

\begin{tabular}{|c|c|c|c|c|c|}
\hline & Germany & UK & France & Italy & Spain \\
\hline $\begin{array}{l}\text { Reading: at least one } \\
\text { book in the last year }\end{array}$ & $79 \%$ & $80 \%$ & $73 \%$ & $56 \%$ & $60 \%$ \\
\hline Type & $\begin{array}{l}\text { Literature and Fiction } \\
(33.8 \%) \\
\text { Children and young } \\
\text { adult }(15.2 \%) \\
\text { Handbooks and } \\
\text { reference works } \\
(13.9 \%)\end{array}$ & $\begin{array}{l}\text { Paperback fiction } \\
(30.7 \%) \text { (in 2010) } \\
\text { Children's books } \\
(29.7 \%) \text { (in 2010) }\end{array}$ & $\begin{array}{l}\text { Literature }(24.2 \%) \\
\text { Practical books and } \\
\text { reference works } \\
(16.8 \%) \\
\text { Children and young } \\
\text { adult }(13.4 \%)\end{array}$ & $\begin{array}{l}\text { Fiction 39\% (2013) } \\
\text { Children's books 19\% } \\
\text { General non-fiction } \\
17 \%\end{array}$ & $\begin{array}{l}\text { Non-university texts } \\
(31.3 \%) \\
\text { Literature }(19.9 \%) \\
\text { Children and young } \\
\text { adult }(12.2 \%)\end{array}$ \\
\hline Distribution & $\begin{array}{l}\text { Bookstores }(49.7 \%) \\
\text { Catalogue }(18 \%) \\
\text { Direct sales from } \\
\text { publisher }(19.1 \%)\end{array}$ & $\begin{array}{l}\text { Bookstore chains } \\
(33 \%) \\
\text { Supermarkets (9\%) } \\
\text { Internet }(35 \%)\end{array}$ & $\begin{array}{l}\text { Bookstores }(23.4 \%) \\
(2010) \\
\text { Specialised culture } \\
\text { stores }(22.3 \%) \\
\text { Hypermarkets }(19.1 \%)\end{array}$ & $\begin{array}{l}\text { Chains }(40.8 \%)(2013) \\
\text { Bookstores }(30.5 \%) \\
\text { Large distributors } \\
(24.0 \%)\end{array}$ & $\begin{array}{l}\text { Bookstores /Bookstore } \\
\text { chains }(55.5 \%) \\
\text { Department stores }\end{array}$ \\
\hline $\begin{array}{l}\text { Active publishing } \\
\text { firms }\end{array}$ & 1,803 & 2,200 & 1,000 & $2,225(2012)$ & 3,187 (2012) \\
\hline Publications & 96,279 new book titles & $\begin{array}{l}170,267 \text { total } \\
\text { publications }\end{array}$ & $\begin{array}{l}64,347 \text { new titles and } \\
\text { new editions }\end{array}$ & $54,057(2010)$ & $\begin{array}{l}104,724 \text { total } \\
\text { publications (2012) }\end{array}$ \\
\hline $\begin{array}{l}\text { turnover at market } \\
\text { prices }\end{array}$ & 9,601 million $€$ & 3,128 million pounds & 2,838 million $€(2010)$ & 3,417 million $€$ & $1,840.5$ million $€$ \\
\hline VAT & $\begin{array}{l}7 \% \text { printed book } \\
19 \% \text { digital book }\end{array}$ & $\begin{array}{l}0 \% \text { printed book } \\
20 \% \text { digital book }\end{array}$ & $\begin{array}{l}5.5 \% \text { printed book } \\
7 \% \text { digital book }\end{array}$ & $\begin{array}{l}4 \% \text { printed book } \\
21 \% \text { digital book }\end{array}$ & $\begin{array}{l}4 \% \text { printed book } \\
21 \% \text { digital book }\end{array}$ \\
\hline Exports & 1,182 million $€$ & $\begin{array}{l}\text { European Union } \\
(44 \%) \\
\text { Asia and Oceania } \\
(23 \%) \\
\text { North America }(13 \%)\end{array}$ & 642 million $€(2010)$ & 42 million $€$ & $\begin{array}{l}506.53 \text { million Euros } \\
\text { turnover }\end{array}$ \\
\hline Exports & $\begin{array}{l}\text { Austria (31\%) } \\
\text { Switzerland (26\%) } \\
\text { France (9\%) } \\
\text { UK (9\%) }\end{array}$ & $\begin{array}{l}10 \text { countries, } \\
\text { prominent amongst } \\
\text { which are: USA (11\%), } \\
\text { Germany }(10 \%) \text { and } \\
\text { Australia }(9 \%) \\
\text { Rest of the world } \\
(43 \%)\end{array}$ & $\begin{array}{l}\text { French-speaking } \\
(78 \%) \\
\text { Belgium, Switzerland, } \\
\text { Canada, Maghreb, } \\
\text { Sub-Saharan Africa } \\
\text { Rest of Europe and } \\
\text { USA }\end{array}$ & & $\begin{array}{l}\text { European Union } \\
62.3 \% \text { of turnover } \\
\text { Latin America } 31.8 \% \\
\text { of turnover } \\
\text { North America } 2.8 \% \text { of } \\
\text { turnover }\end{array}$ \\
\hline $\begin{array}{l}\text { Translations from } \\
\text { other languages }\end{array}$ & $\begin{array}{l}\text { Translated works: } \\
12.3 \% \\
\text { English }(63.8 \%) \\
\text { French }(10.4 \%) \\
\text { Japanese }(6 \%) \\
\text { Italian (3\%) }\end{array}$ & $\begin{array}{l}\text { Translated works: } 3 \% \\
\text { German } \\
\text { French } \\
\text { Spanish }\end{array}$ & $\begin{array}{l}\text { Translated works } \\
15.9 \% \\
\text { English }(59.9 \%) \\
\text { Japanese }(8.8 \%) \\
\text { German }(6.5 \%) \\
\text { Italian }(4.6 \%) \\
\text { Spanish }(3.6 \%)(2010)\end{array}$ & $\begin{array}{l}\text { Translated works: } \\
19.7 \% \\
\text { English }(59.2 \%) \\
\text { French }(14.1 \%) \\
\text { German }(10.4 \%) \\
\text { Spanish }(3.9 \%)(2010)\end{array}$ & $\begin{array}{l}\text { Translated works } 22 \% \\
(2012) \\
\text { English }(51.2 \%) \\
\text { French }(10.3 \%) \\
\text { Italian }(6.2 \%) \\
\text { German }(5.1 \%)\end{array}$ \\
\hline $\begin{array}{l}\text { Translations into } \\
\text { other languages }\end{array}$ & $\begin{array}{l}\text { Chinese / Russian / } \\
\text { Spanish / English / } \\
\text { Polish / Italian / } \\
\text { French / Czech / } \\
\text { Korean / Dutch }\end{array}$ & & $\begin{array}{l}\text { Spanish / Chinese / } \\
\text { Italian / Korean / } \\
\text { German / Dutch / } \\
\text { English / Portuguese / } \\
\text { Russian / Turkish }\end{array}$ & & \\
\hline
\end{tabular}

Source: Own, based on the European Commission (2013) for data on reading habits, Bayón (2012) for data from Germany, Campos (2012) for data from the UK, Carranza (2012) for data from France, Leturia (2013) for data from Italy, and Observatorio de la lectura y el libro (2013) for data from Spain. 


\section{EMPIRICAL STUDY. FACTORIAL AND CLUSTER ANALYSIS}

After this global view of the European publishing sector, we conduct an empirical analysis of the available financial data corresponding to a selection of European firms. Data are taken from the Analyse Major Database from European Sources (Amadeus), drawn up by the Van Dijk Bureau. The variables used in this study are shown in Table 2, given their definition and significance, may be grouped into three categories: size variables (OPRE, PL, TOAS and NE), profitability variables (R1, R2, R3, R4, R5, R6, R7, R8, R9 and R10) and financial structure variables (S1, S2, S3, S4, S5 and S6).

Table 2

Variables: codes and description

\begin{tabular}{|c|c|c|}
\hline Code & Variables & Description \\
\hline OPRE & Operating revenue (Turnover) th. EUR & $\begin{array}{l}\text { Total operating revenues (Net sales + Other operating revenues+ Stock } \\
\text { variations). The figures do not include VAT }\end{array}$ \\
\hline PL & $P / L$ for period (Net Income) th. EUR & $\begin{array}{l}\text { Net income for the year before deduction of minority interests if any } \\
\text { (Profit after taxation + Extraordinary and other profit). }\end{array}$ \\
\hline TOAS & Total assets th. EUR & Total assets (Fixed assets + Current assets) \\
\hline NE & Number of employees (last value) & Total number of employees \\
\hline R1 & ROE using P/L before tax (\%) & (Profit before tax / Shareholders funds) * 100 \\
\hline $\mathrm{R} 2$ & ROCE using P/L before tax (\%) & $\begin{array}{l}\text { (Profit before tax }+ \text { Interest paid) / (Shareholders funds + Non current } \\
\text { liabilities) * } 100\end{array}$ \\
\hline R3 & ROA using P/L before tax (\%) & (Profit before tax / Total assets) $* 100$ \\
\hline R4 & ROE using Net income (\%) & (Net income / Shareholder funds) * 100 \\
\hline R5 & ROCE using Net income (\%) & $\begin{array}{l}\text { (Net income }+ \text { Interest paid) / (Shareholder funds + Non current } \\
\text { liabilities)* } 100\end{array}$ \\
\hline R6 & ROA using Net income (\%) & (Net income / Total Assets) * 100 \\
\hline $\mathrm{R} 7$ & Profit margin (\%) & (Profit before tax / Operating revenue) * 100 \\
\hline $\mathrm{R} 8$ & EBITDA margin (\%) & $($ EBITDA / Operating revenue $) * 100$ \\
\hline R9 & EBIT margin (\%) & $($ EBIT / Operating revenue $) * 100$ \\
\hline R10 & Cash flow / Operating revenue (\%) & $($ Cash flow / Operating revenue $) * 100$ \\
\hline S1 & Current ratio & Current assets / Current liabilities \\
\hline S2 & Liquidity ratio & (Current assets - Stocks) / Current liabilities \\
\hline S3 & Shareholders liquidity ratio & Shareholders funds / Non current liabilities \\
\hline S4 & Solvency ratio (Asset based) (\%) & (Shareholders funds / Total assets) $* 100$ \\
\hline S5 & Solvency ratio (Liability based) (\%) & $($ Shareholders funds / (Non current liabilities + Current liabilities)) * 100 \\
\hline S6 & Gearing (\%) & $(($ Non current liabilities + Loans $) /$ Shareholders funds $) * 100$ \\
\hline
\end{tabular}

Source: Own, based on Amadeus (2016).

The book publishing sector is vast, and is highly concentrated since there is a small group of large firms that dominate the market together with many small and medium firms whose reach is less. In addition, there are notable differences between countries, in turnover, in consumer habits, demand, external impact, etc. For these reasons, by successfully applying multivariate reduction techniques and 
data classification, we select a set of EU-28 ${ }^{10}$ firms, specifically the 123 firms belonging to the book publishing sector (NACE code 5811), whose operating revenue exceeded $10,000,000 €$ in 2012. In this set of firms comprising fifteen countries, those most strongly represented are the five leading countries in Europe (Germany, the UK, France, Italy and Spain), Sweden and Belgium. It can once again be seen that this sector is highly concentrated, given that the seven countries with most firms in this group account for $92 \%$ of the total analysed. Table 3 provides a descriptive analysis of the variables studied. An initial observation of the data reveals that the Pearson variation coefficients are extremely high, indicating major dispersion in all the variables.

Mean data point to a sector which is strong in all its financial variables, displaying healthy profits and sufficient liquidity. The most stable variables in the sample analysed emerge as those linked to liquidity (S1 and S2) and solvency (S4 and S5) given that their coefficients of variation appear as the lowest.

Table 3

Descriptive analysis

\begin{tabular}{ccrrrrrr}
\hline & N & \multicolumn{1}{c}{ Mean } & \multicolumn{1}{c}{ Median } & \multicolumn{1}{c}{ Std. Dev. } & Coeff. Var. (\%) & \multicolumn{1}{c}{ Minimun } & \multicolumn{1}{c}{ Maximun } \\
\hline OPRE & 123 & 100268.808 & 27399.635 & 283166.094 & 282.407 & 10047.635 & 1995700.000 \\
PL & 123 & 5015.932 & 696.987 & 17508.929 & 349.066 & -12941.778 & 128900.000 \\
TOAS & 123 & 125627.401 & 21709.884 & 395164.022 & 314.552 & 3406.884 & 3145954.000 \\
NE & 123 & 390.008 & 76.000 & 1309.391 & 335.734 & 8.000 & 10152.000 \\
\hline R1 & 123 & 14.327 & 14.905 & 43.388 & 302.841 & -176.188 & 132.691 \\
R2 & 123 & 16.145 & 13.856 & 30.206 & 187.092 & -96.528 & 111.789 \\
R3 & 123 & 5.848 & 4.620 & 11.332 & 193.776 & -16.743 & 66.041 \\
R4 & 123 & 7.786 & 10.938 & 42.348 & 543.899 & -164.927 & 110.008 \\
R5 & 123 & 11.450 & 11.046 & 26.396 & 230.533 & -96.528 & 97.474 \\
R6 & 123 & 3.947 & 2.824 & 9.391 & 237.928 & -21.578 & 45.270 \\
R7 & 123 & 4.777 & 3.367 & 8.989 & 188.172 & -20.341 & 35.479 \\
R8 & 123 & 9.286 & 7.118 & 10.333 & 111.275 & -16.504 & 48.004 \\
R9 & 123 & 5.451 & 4.462 & 8.317 & 152.578 & -17.699 & 35.442 \\
R10 & 123 & 6.973 & 5.692 & 9.663 & 138.577 & -20.810 & 45.019 \\
\hline S1 & 123 & 1.420 & 1.369 & 0.516 & 36.338 & 0.312 & 3.207 \\
S2 & 123 & 1.130 & 1.078 & 0.527 & 46.637 & 0.273 & 3.174 \\
S3 & 108 & 19.771 & 3.102 & 61.598 & 311.557 & 0.151 & 463.096 \\
S4 & 123 & 29.108 & 29.559 & 12.492 & 42.916 & 3.039 & 49.843 \\
S5 & 123 & 45.573 & 41.963 & 26.242 & 57.582 & 3.134 & 99.373 \\
S6 & 123 & 117.147 & 46.146 & 167.637 & 143.100 & 0.000 & 999.456 \\
\hline
\end{tabular}

Source: Own elaboration.

The formulation of the work consists of conducting factorial analysis of the initial information matrix comprising 123 firms and 20 variables. The aim is to construct new variables based on the initial ones, provided they are not correlated with one another and that they explain the highest possible percentage of joint variance of the original variables. These new variables or factors are obtained using the principal component method, with varimax rotation so as to improve the

${ }^{10}$ See country codes in Table A1. 
interpretation of the results. After carrying out an initial test introducing all the variables in the model, it was seen that variable S3 displayed extremely low communality (0.269). In other words, the proportion of S3 variance that might be explained by the factorial model is very small, which is why it was decided to exclude it from the analysis. When repeating the same procedure with all the variables except for S3, the following results were obtained.

Firstly, there are strong correlations among the chosen variables, thus bearing out the timeliness of performing factorial analysis to reduce the dimensions. Table 4 shows the results of the various adequacy tests of factorial analysis to the data. Bartlett's Test of Sphericity verifies whether the correlation matrix is the identity. In our case, the hypothesis is rejected, evidencing that the variables in the model are correlated. The Kaiser-Meyer-Olkin Measure comparing correlation coefficients with the partial correlations and with a value of 0.665 performing factorial analysis is acceptable. Table 5 shows the communalities of the variables involved in the model.

Table 4

$\mathrm{KMO}$ and Bartlett's test

\begin{tabular}{llr}
\hline Kaiser-Meyer-Olkin Measure of Sampling Adequacy & .665 \\
& Approx. Chi-square & 4279.415 \\
Bartlett's Test of Sphericity & df & 171 \\
& Sig. & .000 \\
\hline
\end{tabular}

Source: Own elaboration.

Table 5

Communalities

\begin{tabular}{ccc}
\hline & Initial & Extraction \\
\hline OPRE & 1.000 & .995 \\
PL & 1.000 & .900 \\
TOAS & 1.000 & .848 \\
NE & 1.000 & .946 \\
R1 & 1.000 & .892 \\
R2 & 1.000 & .920 \\
R3 & 1.000 & .871 \\
R4 & 1.000 & .828 \\
R5 & 1.000 & .910 \\
R6 & 1.000 & .886 \\
R7 & 1.000 & .901 \\
R8 & 1.000 & .943 \\
R9 & 1.000 & .884 \\
R10 & 1.000 & .859 \\
S1 & 1.000 & .941 \\
S2 & 1.000 & .926 \\
S4 & 1.000 & .955 \\
S5 & 1.000 & .925 \\
S6 & 1.000 & .694 \\
\hline
\end{tabular}

Source: Own elaboration. 
Table 6

Total variance explained

\begin{tabular}{|c|c|c|c|c|c|c|c|c|c|}
\hline \multirow[b]{2}{*}{ Component } & \multicolumn{3}{|c|}{ Initial Eigenvalues } & \multicolumn{3}{|c|}{$\begin{array}{l}\text { Extraction Sums of Squared } \\
\text { Loadings }\end{array}$} & \multicolumn{3}{|c|}{$\begin{array}{l}\text { Rotation Sums of Squared } \\
\text { Loadings }\end{array}$} \\
\hline & Total & $\begin{array}{c}\% \text { of } \\
\text { variance }\end{array}$ & $\begin{array}{c}\text { Cumulative } \\
\%\end{array}$ & Total & $\begin{array}{c}\% \text { of } \\
\text { variance }\end{array}$ & $\begin{array}{c}\text { Cumulative } \\
\%\end{array}$ & Total & $\begin{array}{c}\% \text { of } \\
\text { variance }\end{array}$ & $\begin{array}{c}\text { Cumulative } \\
\%\end{array}$ \\
\hline 1 & 8.235 & 43.345 & 43.345 & 8.235 & 43.345 & 43.345 & 5.856 & 30.821 & 30.821 \\
\hline 2 & 3.632 & 19.116 & 62.460 & 3.632 & 19.116 & 62.460 & 3.675 & 19.341 & 50.162 \\
\hline 3 & 2.090 & 10.999 & 73.459 & 2.090 & 10.999 & 73.459 & 3.009 & 15.834 & 65.996 \\
\hline 4 & 1.790 & 9.419 & 82.878 & 1.790 & 9.419 & 82.878 & 2.530 & 13.314 & 79.310 \\
\hline 5 & 1.276 & 6.716 & 89.594 & 1.276 & 6.716 & 89.594 & 1.954 & 10.284 & 89.594 \\
\hline 6 & .478 & 2.517 & 92.111 & & & & & & \\
\hline 7 & .440 & 2.316 & 94.427 & & & & & & \\
\hline 8 & .271 & 1.424 & 95.852 & & & & & & \\
\hline 9 & .209 & 1.097 & 96.949 & & & & & & \\
\hline 10 & .194 & 1.020 & 97.970 & & & & & & \\
\hline 11 & .134 & .707 & 98.677 & & & & & & \\
\hline 12 & .107 & .564 & 99.240 & & & & & & \\
\hline 13 & .054 & .285 & 99.526 & & & & & & \\
\hline 14 & .042 & .223 & 99.748 & & & & & & \\
\hline 15 & .027 & .143 & 99.891 & & & & & & \\
\hline 16 & .011 & .060 & 99.951 & & & & & & \\
\hline 17 & .005 & .025 & 99.976 & & & & & & \\
\hline 18 & .003 & .018 & 99.993 & & & & & & \\
\hline 19 & .001 & .007 & 100.000 & & & & & & \\
\hline
\end{tabular}

Extraction Method: Principal Component Analysis.

Source: Own elaboration.

Based on the 19 initial variables, the factorial model extracts five factors which explain 89.549\% of total variance. These are specified in Table 6 with the percentages of variance explained by each factor. Table 7 shows the coefficients of the factors already rotated.

Taking into account the correlations of the variables with the extracted factors, the following interpretation might be made of these:

- F1. Profitability: a factor highly correlated with ROE, ROCE and ROA (ratios R1, R2, R3, R4, R5, and R6). It measures the economic and financial profitability of firms, in other words, with regard to assets and liabilities. It is quite closely linked to firm size.

- F2. Size of the firm: a factor highly correlated with the variables: OPRE, PL, TOAS and NE.

- F3. Margin: a factor highly correlated with ratios R7, R8, R9, R10, which measure the profit margin or operating profitability.

- F4: Solvency: a factor positively correlated with solvency ratios (S4 and S5) and negatively with gearing (S6).

- F5: Liquidity: a factor correlated with S1 and S2, which are the current liquidity ratio and the acid test. 
Table 7

Rotated components matrix

\begin{tabular}{llllll}
\hline & \multicolumn{5}{c}{ Component } \\
\cline { 2 - 6 } & $\mathbf{1}$ & $\mathbf{2}$ & $\mathbf{3}$ & $\mathbf{4}$ & $\mathbf{5}$ \\
\hline R5 & .932 & .013 & .193 & .065 & .008 \\
R2 & .921 & -.001 & .255 & .076 & -.023 \\
R1 & .904 & .026 & .223 & .135 & .075 \\
R4 & .882 & .036 & .103 & .160 & .116 \\
R6 & .852 & .020 & .336 & .185 & .109 \\
R3 & .821 & .013 & .394 & .184 & .092 \\
OPRE & .010 & .997 & .012 & .020 & -.020 \\
NE & .009 & .971 & -.019 & .040 & -.002 \\
PL & .113 & .928 & .114 & .100 & -.054 \\
TOAS &. .028 & .917 & .068 & -.046 & .019 \\
R8 & .323 & .062 & .913 & .038 & .024 \\
R10 & .375 & .028 & .844 & .070 & .006 \\
R9 & .582 & .117 & .701 & .188 & .067 \\
R7 & .631 & .085 & .671 & .209 & .040 \\
S4 & .144 & .066 & .162 & .940 & .142 \\
S5 & .105 & .046 & .172 & .925 & .160 \\
\hline S6 &. .309 & .012 & .071 & -.747 & .189 \\
S1 & .089 & -.032 & -.042 & .105 & .959 \\
S2 & .111 & -.018 & .100 & .003 & .950 \\
\hline
\end{tabular}

Extraction Method: Principal Component Analysis.

Rotation Method: Varimax with Kaiser Normalization.

Rotation converged in 5 iterations.

Source: Own elaboration.

The factorial scores estimated for each of the firms, used as classifying variables, allow a cluster analysis to be conducted grouping the firms studied using similarity criteria. At an initial exploratory stage, the study is carried out hierarchically using the Ward method with which it can be deduced, using the agglomeration schedule, that the appropriate number of clusters to be chosen in our case is five. At the second stage, a k-means cluster analysis is performed with the number of groups determined in the previous step. In order to describe each of the clusters correctly, for each factor Tables 8 to 12 provide the minimum and maximum percentile of the firms that make up the cluster, as well as the percentage of firms that are inside each interval delimited by the quartiles. Figures 1 to 5 show the centroids of the clusters. Information concerning the firms that make up each cluster is shown in Tables A2 to A6 of the Annex.

\section{Cluster 1: Leading publishing companies}

This cluster is composed of the four largest firms in our set of data. These firms occupy a leading position in the sector due to their size and they show profit and solvency ratios above mean, reflecting good financial management. This group also displays values that are slightly below the mean of the 123 
firms analysed with regard to profit margin and liquidity. The two most profitable firms are the two UK firms (HM Publishers Holdings Limited and Holtzbrinck Publishers Holdings Limited), followed by the German firm Verlagsgruppe Georg von Holtzbrinck Gesellschaft mit beschränkter Haftung and the Spanish firm Planeta Corporación SL.

Table 8

Description of Cluster 1 in terms of its percentiles and quartiles

\begin{tabular}{lcccrrr}
\hline \multicolumn{1}{c}{ Cluster 1 } & Min percentile & Max percentile & $\mathbf{Q}_{\mathbf{1}}$ (\%) & $\mathbf{Q}_{\mathbf{2}}$ (\%) & \multicolumn{1}{c}{$\mathbf{Q}_{\mathbf{3}}$ (\%) } & $\mathbf{Q}_{\mathbf{4}}$ (\%) \\
\hline F1: Profitability & 40 & 71 & 0.00 & 25.00 & $\mathbf{7 5 . 0 0}$ & 0.00 \\
F2: Size & 98 & 100 & 0.00 & 0.00 & 0.00 & $\mathbf{1 0 0 . 0 0}$ \\
F3: Margin & 46 & 68 & 0.00 & 75.00 & 25.00 & 0.00 \\
F4: Solvency & 32 & 77 & 0.00 & 75.00 & 0.00 & 25.00 \\
F5. Liquidity & 5 & 77 & 25.00 & 0.00 & $\mathbf{5 0 . 0 0}$ & $\mathbf{2 5 . 0 0}$ \\
\hline
\end{tabular}

Source: Own elaboration.

Figure 1

Cluster 1: centroids

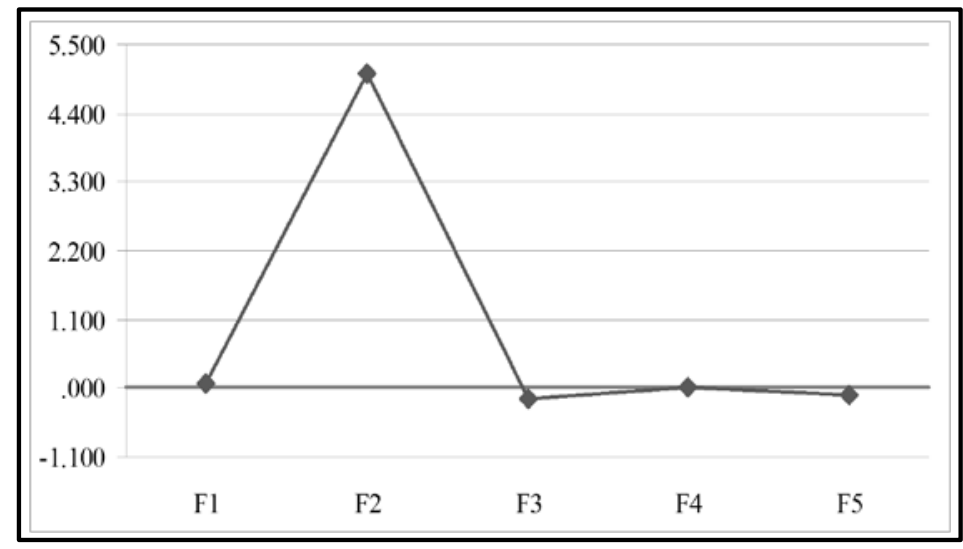

Source: Own elaboration.

\section{Cluster 2: Traditional publishing companies}

This cluster is composed of 39 firms, its main feature being that it exhibits extremely high levels of solvency and liquidity, low profitability and margin ratios, as well as diverse size. This is a large group of firms which display good structure ratios although in the year studied, they did not perform too well. $28.21 \%$ of this cluster's composition is UK, 23.08\% Spanish and 17.85\% Italian. 
Table 9

Description of Cluster 2 in terms of its percentiles and quartiles

\begin{tabular}{lcccccc}
\hline \multicolumn{1}{r}{ Cluster 2 } & Min percentile & Max percentile & $\mathbf{Q}_{\mathbf{1}}$ (\%) & $\mathbf{Q}_{\mathbf{2}}$ (\%) & $\mathbf{Q}_{\mathbf{3}}$ (\%) & $\mathbf{Q}_{\mathbf{4}}$ (\%) \\
\hline F1: Profitability & 3 & 76 & $\mathbf{3 5 . 9 0}$ & $\mathbf{3 3 . 3 3}$ & 28.21 & 2.56 \\
F2: Size & 9 & 97 & 20.51 & 33.33 & 30.77 & 15.38 \\
F3: Margin & 2 & 84 & $\mathbf{2 3 . 0 8}$ & $\mathbf{3 8 . 4 6}$ & 33.33 & 5.13 \\
F4: Solvency & 48 & 100 & 0.00 & 2.56 & $\mathbf{3 8 . 4 6}$ & $\mathbf{5 8 . 9 7}$ \\
F5. Liquidity & 11 & 98 & 7.69 & 28.21 & $\mathbf{3 8 . 4 6}$ & $\mathbf{2 5 . 6 4}$ \\
\hline
\end{tabular}

Source: Own elaboration.

Figure 2

Cluster 2: centroids

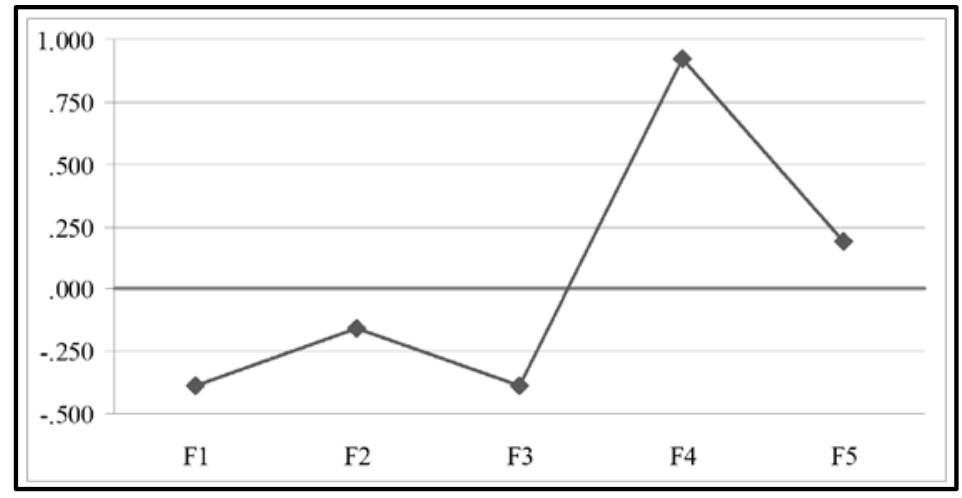

Source: Own elaboration.

\section{Cluster 3: Unusual publishing companies}

This cluster comprises a small number of companies (5) which evidenced high liquidity and margins in 2012, yet displayed low solvency and profitability, their size varying substantially. It is worrying that working with good margins they fail to secure greater profitability. This might be due to the cost they bear resulting from their high level of debt, which entails greater financial costs. Two of the five firms are located in Germany.

Table 10

Description of Cluster 3 in terms of its percentiles and quartiles

\begin{tabular}{lccrrrr}
\hline \multicolumn{1}{c}{ Cluster 3 } & Min percentile & Max percentile & $\mathbf{Q}_{\mathbf{1}}(\%)$ & $\mathbf{Q}_{\mathbf{2}}(\%)$ & $\mathbf{Q}_{\mathbf{3}}(\%)$ & $\mathbf{Q}_{\mathbf{4}}(\%)$ \\
\hline F1: Profitability & 7 & 31 & $\mathbf{8 0 . 0 0}$ & $\mathbf{2 0 . 0 0}$ & 0.00 & 0.00 \\
F2: Size & 10 & 95 & 20.00 & 20.00 & 20.00 & 40.00 \\
F3: Margin & 42 & 98 & 0.00 & 20.00 & $\mathbf{2 0 . 0 0}$ & $\mathbf{6 0 . 0 0}$ \\
F4: Solvency & 2 & 19 & $\mathbf{1 0 0 . 0 0}$ & 0.00 & 0.00 & 0.00 \\
F5. Liquidity & 94 & 100 & 0.00 & 0.00 & 0.00 & $\mathbf{1 0 0 . 0 0}$ \\
\hline
\end{tabular}

Source: Own elaboration. 
Figure 3

Cluster 3: centroids

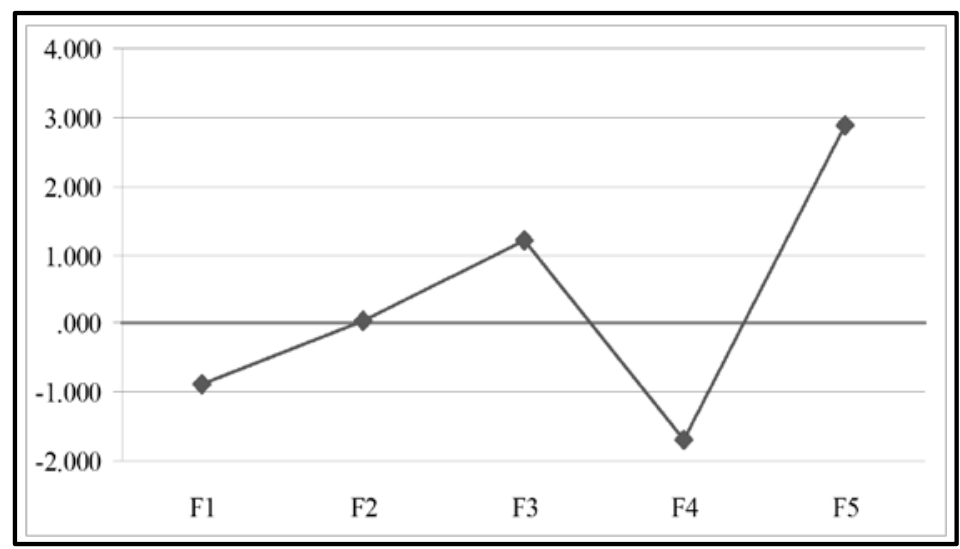

Source: Own elaboration.

\section{Cluster 4: Publishing companies experiencing difficulties}

This is the most numerous cluster, comprising 45 firms ranging in size, and which display low ratios in all the factors analysed, particularly in terms of solvency. This suggests that a substantial number of companies might have been experiencing difficulties during the period analysed. $24.44 \%$ of the firms in this group are Italian, $15.56 \%$ UK, $13.33 \%$ French and $11.11 \%$ Belgian.

Figure 4

Cluster 4: centroids

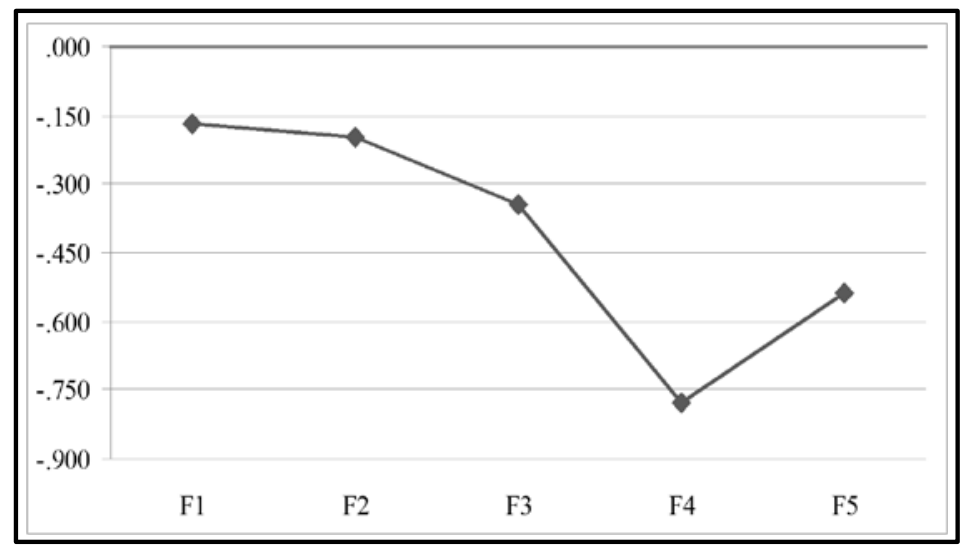

Source: Own elaboration. 
Table 11

Description of Cluster 4 in terms of its percentiles and quartiles

\begin{tabular}{lccrrrr}
\hline \multicolumn{1}{c}{ Cluster $\mathbf{4}$} & Min percentile & Max percentile & $\mathbf{Q}_{\mathbf{1}}(\mathbf{\%})$ & $\mathbf{Q}_{\mathbf{2}}(\mathbf{\%})$ & $\mathbf{Q}_{\mathbf{3}}(\mathbf{\%})$ & $\mathbf{Q}_{\mathbf{4}}(\%)$ \\
\hline F1: Profitability & 1 & 95 & 26.67 & 28.89 & 22.22 & 22.22 \\
F2: Size & 15 & 92 & 8.89 & 33.33 & 31.11 & 26.67 \\
F3: Margin & 1 & 88 & $\mathbf{4 2 . 2 2}$ & $\mathbf{2 2 . 2 2}$ & 20.00 & 15.56 \\
F4: Solvency & 1 & 57 & $\mathbf{5 1 . 1 1}$ & $\mathbf{4 2 . 2 2}$ & 6.67 & 0.00 \\
F5. Liquidity & 1 & 88 & $\mathbf{5 1 . 1 1}$ & $\mathbf{2 8 . 8 9}$ & 11.11 & 8.89 \\
\hline
\end{tabular}

Source: Own elaboration.

\section{Cluster 5: "Boutique" publishing companies}

This is a large cluster, comprising 30 firms characterised by their very high profitability and margin ratios, and with high solvency and liquidity. The firms are basically quite small. This might lead us to think that they are specialised firms catering to a select yet small group of clients, which would allow them to perform well. In this cluster, $30.00 \%$ of the firms are Italian, 20.00\% Swedish and $16.67 \%$ French.

Table 12

Description of Cluster 5 in terms of its percentiles and quartiles

\begin{tabular}{lcccccc}
\hline \multicolumn{1}{c}{ Cluster $\mathbf{5}$} & Min percentile & Max percentile & $\mathbf{Q}_{\mathbf{1}}(\mathbf{\%})$ & $\mathbf{Q}_{\mathbf{2}}(\mathbf{\%})$ & $\mathbf{Q}_{\mathbf{3}}(\%)$ & $\mathbf{Q}_{\mathbf{4}}(\%)$ \\
\hline F1: Profitability & 14 & 100 & 3.33 & 10.00 & $\mathbf{2 0 . 0 0}$ & $\mathbf{6 6 . 6 7}$ \\
F2: Size & 1 & 96 & $\mathbf{6 0 . 0 0}$ & $\mathbf{6 . 6 7}$ & 10.00 & 23.33 \\
F3: Margin & 7 & 100 & 10.00 & 6.67 & $\mathbf{2 0 . 0 0}$ & $\mathbf{6 3 . 3 3}$ \\
F4: Solvency & 14 & 92 & 10.00 & 26.67 & $\mathbf{4 0 . 0 0}$ & $\mathbf{2 3 . 3 3}$ \\
F5. Liquidity & 2 & 95 & 13.33 & 23.33 & $\mathbf{2 6 . 6 7}$ & $\mathbf{3 6 . 6 7}$ \\
\hline
\end{tabular}

Source: Own elaboration.

Figure 5

Cluster 5: centroids

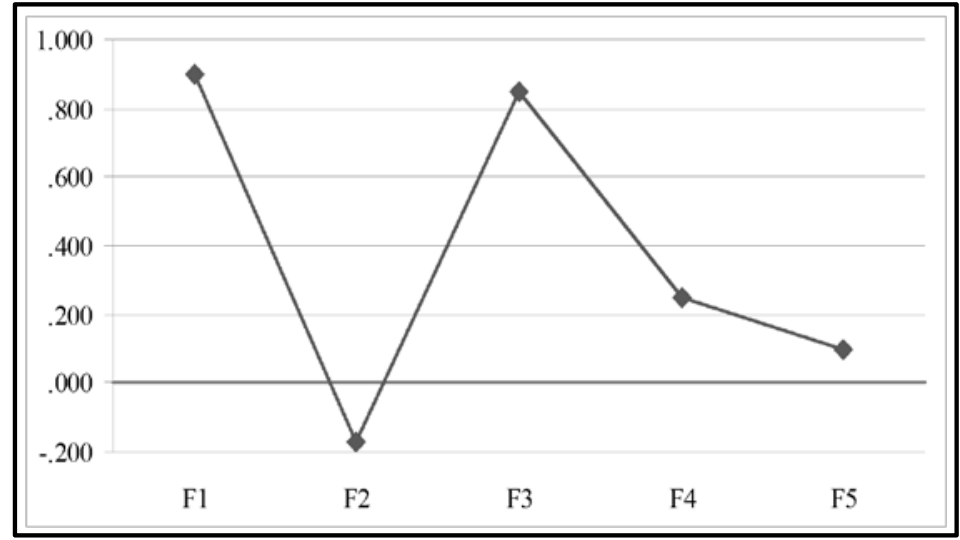

Source: Own elaboration. 
To sum up the group analysis conducted, we may conclude that the clusters vary enormously in size. The information given by Table 13 points to two groups of firms -leading firms (C1) and unusual firms (C3)- which, although small in number, evidence certain highly differentiating factors that set them apart from the rest.

Table 13

Distances between centroids of clusters

\begin{tabular}{cccccc}
\hline Cluster & $\mathbf{1}$ & $\mathbf{2}$ & $\mathbf{3}$ & $\mathbf{4}$ & $\mathbf{5}$ \\
\hline 1 & & 5.302 & 6.308 & 5.314 & 5.380 \\
2 & 5.302 & & 4.118 & 1.864 & 1.918 \\
3 & 6.308 & 4.118 & & 3.946 & 3.864 \\
4 & 5.314 & 1.864 & 3.946 & & 2.006 \\
5 & 5.380 & 1.918 & 3.864 & 2.006 & \\
\hline
\end{tabular}

Source: Own elaboration.

Table 14

Distribution of the sample by cluster and by country

\begin{tabular}{|c|c|c|c|c|c|c|c|c|c|c|c|c|}
\hline \multirow[b]{2}{*}{ Country } & \multirow[b]{2}{*}{$\%$} & \multicolumn{5}{|c|}{$\%$ by cluster } & \multicolumn{5}{|c|}{$\%$ by country } & \multirow[b]{2}{*}{ Total } \\
\hline & & C1 & $\mathrm{C} 2$ & C3 & C4 & C5 & C1 & C2 & C3 & C4 & C5 & \\
\hline IT & 22.8 & & 17.95 & 20.00 & 24.44 & 30.00 & & 25.00 & 3.57 & 39.29 & 32.14 & 100 \\
\hline GB & 19.5 & 50.00 & 28.21 & 20.00 & 15.56 & 10.00 & 8.33 & 45.83 & 4.17 & 29.17 & 12.50 & 100 \\
\hline ES & 13.0 & 25.00 & 23.08 & & 8.89 & 6.67 & 6.25 & 56.25 & & 25.00 & 12.50 & 100 \\
\hline FR & 12.2 & & 7.69 & 20.00 & 13.33 & 16.67 & & 20.00 & 6.67 & 40.00 & 33.33 & 100 \\
\hline SE & 8.9 & & 7.69 & & 4.44 & 20.00 & & 27.27 & & 18.18 & 54.55 & 100 \\
\hline $\mathrm{BE}$ & 7.3 & & 5.13 & & 11.11 & 6.67 & & 22.22 & & 55.56 & 22.22 & 100 \\
\hline DE & 7.3 & 25.00 & 5.13 & 40.00 & 8.89 & & 11.11 & 22.22 & 22.22 & 44.44 & & 100 \\
\hline $\mathrm{FI}$ & 2.4 & & 2.56 & & 2.22 & 3.33 & & 33.33 & & 33.33 & 33.33 & 100 \\
\hline PL & 1.6 & & & & 4.44 & & & & & 100 & & 100 \\
\hline$C Z$ & .8 & & & & 2.22 & & & & & 100 & & 100 \\
\hline GR & .8 & & 2.56 & & & & & 100 & & & & 100 \\
\hline IE & .8 & & & & & 3.33 & & & & & 100 & 100 \\
\hline LU & .8 & & & & & 3.33 & & & & & 100 & 100 \\
\hline PT & .8 & & & & 2.22 & & & & & 100 & & 100 \\
\hline SK & .8 & & & & 2.22 & & & & & 100 & & 100 \\
\hline Total & 100 & 100 & 100 & 100 & 100 & 100 & & & & & & \\
\hline
\end{tabular}

Source: Own elaboration.

Table 14 shows the dominant countries in each cluster as well as the type of firm, from the financial-economic standpoint, which is most common in each country. Thus, it can be seen that in the sample studied, Italy displays a high percentage of firms in the cluster experiencing the greatest financial difficulties (C4) and in the group of boutique firms (C5); the UK and Spain have around half of their firms in the cluster of so-called traditional firms (C2), which is characterised by its good solvency and liquidity ratios, but which perform poorly in terms of profitability and profit margins, and at least a quarter of the firms in the cluster undergoing the greatest financial difficulties (C4). Sweden 
characteristically exhibits a high percentage of small-sized firms showing good performance in the cluster of boutique firms (C5). In the sample analysed, in 2012 Belgium and Germany evidenced a high percentage of firms experiencing difficulties (C4).

\section{CONCLUSIONS}

1. In the field of cultural industries, the publishing sector occupies a key role thanks to its turnover, the number of jobs it provides, and the possibilities it affords for development due to the combination of new technologies and globalisation. Europe, together with countries such as the USA, China and Japan, hold a dominant position in this sector. Specifically, the five main European powers in the publishing sector in terms of their levels of production and turnover are: Germany, the UK, France, Italy and Spain.

2. The comparative study of the five European powers shows that in these countries the most popular types of books are literature/fiction as well as children and young adult literature. Books are mainly purchased in bookstores or bookstore chains and department stores or supermarkets. The scale of the publishing sector in these five countries is reflected in the number of active publishing companies, which ranges between approximately 1,000 and 3,000, with levels of turnover varying between 1,800 and 9,600 million Euros, and an annual number of publications ranging between 54,000 and 170,000. Exports and translation licences are two important strategies to increase revenue and have helped to improve the situation of firms during the crisis.

3. The empirical study of the 123 firms in our database whose operating revenue exceeds 10,000,000 Euros, extracts five factors which explain 89.549\% of total variance. These factors are: Profitability, Size, Margin, Solvency and Liquidity. A classification of the firms based on the five factors determined allows us to form five clusters of firms: the first comprising four of the largest firms; the second comprising 39 firms, characterised by their high solvency and liquidity, but low profitability and margin; the third comprising five firms displaying high margin and liquidity but low profitability and solvency; the fourth cluster being composed of 45 firms displaying low solvency, liquidity, and margin, and finally the fifth cluster which is composed of 30 rather small firms, yet which display good data in all the factors analysed.

4. The method used has shown itself to be efficient for examining the financial situation of a group of leading European publishing firms in 2012 and has proved useful for designing support strategies for this particular cultural sector in the various countries analysed. Nevertheless, the classification to emerge from the present study has not enabled us to define a ranking of such firms, an issue which might be dealt with through the use of synthetic indicator in future research. 


\section{REFERENCIAS BIBLIOGRÁFICAS}

AMADEUS [Database] (2016). Bruselas etc.: Bureau van Dijk Electronic Publishing.

BAYÓN, R. (2012). El mercado alemán del sector editorial. Düsseldorf: Instituto Español de Comercio Exterior. Oficina Económica y Comercial del Consulado de España.

BOOKNET CANADA (2013). "The Canadian Ebook Market Plateaus at 15\%, Says New BookNet Canada Study". 21 de mayo de 2013. Disponible en http://goo.gl/liojMo [Último acceso: 3 de septiembre de 2016].

BOOKSTATS (2013). "Publishing's Most Comprehensive Annual Survey". 15 de mayo de 2013. Disponible en http://goo.gl/MwTHVp [Último acceso: 3 de septiembre de 2016].

CAMPOS, E. (2012). El libro en Reino Unido. Breve Panorámica 2012. Londres: Instituto Español de Comercio Exterior. Oficina Económica y Comercial de la Embajada de España.

CARRANZA, M. (2012). El mercado del libro en Francia. París: Instituto Español de Comercio Exterior. Oficina Económica y Comercial de la Embajada de España.

CLEE, N. (ed.) (2013). PA Statistics Yearbook 2012. London: Publishers Association.

CONECTA (2013). "Hábitos de lectura y compra de libros en España 2012". Enero 2013. Disponible en http:// http://goo.gl/09PECP [Último acceso: 3 de septiembre de 2016].

DECRETO-LEI N. ${ }^{\circ}$ 176/96, OF 21 SEPTEMBER 1996, INSTITUI O REGIME DO PREÇO FIXO DO LIVRO [Portugal]. Diário da república, 21 de septiembre de 1996, n. 220/96 Série I-A, pp. 3309-3313.

DIRECTIVE 2006/112/EC, OF 28 NOVEMBER 2006, ON THE COMMON SYSTEM OF VALUE ADDED TAX [European Union]. Official Journal of the European Union $L$ 347, 11 de diciembre de 2006, pp. 1-118.

EUROPEAN COMMISSION (2013). "Special Eurobarometer 399. Cultural access and participation report". Noviembre 2013. Disponible en http://goo.gl/AtRw7D [Último acceso: 3 de septiembre de 2016].

FEDERATION OF EUROPEAN PUBLISHERS (2012). "European Book Publishing Statistics 2012". Disponible en http://goo.gl/nCC9JD [Último acceso: 3 de septiembre de 2016].

INTERNATIONAL PUBLISHERS ASSOCIATION (2013). "Annual Report 2012-2013". Disponible en http://goo.gl/BUOhsU [Último acceso: 3 de septiembre de 2016].

LACROIX, C. (2012). Chiffres clés: statistiques de la culture. (Édition 2012). Paris: La documentation française.

LETURIA, I. (2013). El mercado del sector Editorial y Literario en Italia. Milán: Instituto Español de Comercio Exterior. Oficina Económica y Comercial de la Embajada de España.

LEY 10/2007, OF 22 JUNE 2007, DE LA LECTURA, DEL LIBRO Y DE LAS BIBLIOTECAS [España]. Boletín Oficial del Estado, 23 de junio de 2007, n. 150, pp. 27140-27150.

LOI N 81-766, OF 10 AUGUST 1981, RELATIVE AU PRIX DU LIVRE [France]. Journal officiel de la République française, 11 de agosto de 1981, pp. 2198. 
OBSERVATORIO DE LA LECTURA Y EL LIBRO (2013). Boletín $n^{\circ}$ 15. Madrid: Ministerio de Educación, Cultura y Deporte. Secretaría de Estado de Cultura.

PALMA, M.L.; MARTÍN, J.L.; JAÉN, M. (2009). "El mercado del libro en España 19892006. Un análisis económico". Estudios de Economía Aplicada, 27(1), pp. 225-252.

PRICEWATERHOUSECOOPERS S.L. (2013). "Global entertainment and media outlook 2013-2017". Disponible en http://goo.gl/JN9Oya [Último acceso: 3 de septiembre de 2016].

TERA CONSULTANTS (2010). "Building a Digital Economy: The Importance of Saving Jobs in the EU's Creative Industries". Disponible en http://goo.gl/vN8DXz [Último acceso: 3 de septiembre de 2016].

VILLARROYA, A.; ESCARDÍBUL, J.O. (2010). "La demanda de libros y publicaciones periódicas en España". Estudios de Economía Aplicada, 28(1), pp. 195-217. 


\section{Annex}

Table A1

Country codes

\begin{tabular}{|c|c|c|c|c|c|c|c|}
\hline Country & Code & Country & Code & Country & Code & Country & Code \\
\hline Austria & AT & Estonia & EE & Italy & IT & Portugal & PT \\
\hline Belgium & $B E$ & Finland & $\mathrm{FI}$ & Latvia & LV & Romania & RO \\
\hline Bulgaria & BG & France & FR & Lithuania & LT & Slovakia & SK \\
\hline Croatia & HR & Germany & DE & Luxembourg & LU & Slovenia & $\mathrm{SI}$ \\
\hline Cyprus & $\mathrm{CY}$ & Greece & GR & Malta & MT & Spain & ES \\
\hline Czech Republic & $C Z$ & Hungary & $\mathrm{HU}$ & Netherlands & $\mathrm{NL}$ & Sweden & SE \\
\hline Denmark & DK & Ireland & IE & Poland & $\mathrm{PL}$ & United Kingdom & $G B$ \\
\hline
\end{tabular}

Source: Own elaboration.

Table A2

Cluster 1: Firms grouped by country and corresponding percentiles in each factor

\begin{tabular}{|c|c|c|c|c|c|c|c|}
\hline Country & Firm name & & F1 & F2 & F3 & F4 & F5 \\
\hline DE & $\begin{array}{l}\text { Verlagsgruppe Georg von Holtzbrinck } \\
\text { beschänkter Haftung }\end{array}$ & Gesellschaft mit & 55 & 100 & 46 & 77 & 64 \\
\hline ES & Planeta Corporacion SL & & 40 & 99 & 68 & 32 & 5 \\
\hline GB & HM Publishers Holdings Limited & & 71 & 98 & 48 & 50 & 77 \\
\hline GB & Holtzbrinck Publishers Holdings Limited & & 66 & 98 & 49 & 39 & 73 \\
\hline
\end{tabular}

Source: Own elaboration.

Table A3

Cluster 2: Firms grouped by country and corresponding percentiles in each factor

\begin{tabular}{clccccc}
\hline Country & \multicolumn{1}{c}{ Firm name } & F1 & F2 & F3 & F4 & F5 \\
\hline BE & Editions Casterman & 67 & 55 & 41 & 56 & 46 \\
BE & Editions Dupuis & 45 & 50 & 34 & 82 & 33 \\
\hline DE & Carl Hanser Verlags- leitungsgesellschaft mbH & 41 & 78 & 43 & 70 & 81 \\
DE & MVB Marketing- und Verlagsservice des Buchhandels GmbH & 24 & 41 & 50 & 90 & 98 \\
\hline ES & Arkonte Gestion Integral SA & 27 & 91 & 60 & 72 & 28 \\
ES & Distribuidora Vicens Vives SA & 34 & 67 & 20 & 60 & 72 \\
ES & Editorial Casals SA & 21 & 69 & 2 & 55 & 90 \\
ES & Editorial De Serveis d'obres Literaries 90 SL & 37 & 11 & 72 & 88 & 49 \\
ES & Macmillan Iberia SA & 60 & 62 & 54 & 95 & 70 \\
ES & RBA Coleccionables SA & 46 & 77 & 46 & 85 & 37 \\
ES & RBA Holding De Comunicacion SL & 36 & 90 & 63 & 94 & 48 \\
ES & RBA Libros SA & 56 & 13 & 84 & 93 & 32 \\
ES & Santillana Ediciones Generales SL & 11 & 24 & 40 & 85 & 17 \\
\hline FI & Kustannusosakeyhtiö Tammi & 33 & 16 & 53 & 83 & 18 \\
\hline FR & Editions T.I. & 75 & 25 & 29 & 63 & 68 \\
FR & LES Nouvelles Editions De L Universite & 22 & 49 & 15 & 80 & 60 \\
FR & Societe d'information ET De Creations & 3 & 51 & 37 & 64 & 82 \\
\hline GB & Faber And Faber Limited & 54 & 32 & 70 & 93 & 89 \\
GB & Jonathan Goodman Publishing Limited & 72 & 21 & 69 & 97 & 87 \\
GB & Lion Hudson PLC & 5 & 28 & 31 & 100 & 63 \\
GB & Music Sales Group Limited & 20 & 76 & 27 & 73 & 43 \\
GB & Music Sales Limited & 18 & 65 & 6 & 98 & 57 \\
GB & Parragon Books Limited & 10 & 70 & 2 & 99 & 97 \\
\hline
\end{tabular}


Table A3 (Continue)

Cluster 2: Firms grouped by country and corresponding percentiles in each factor

\begin{tabular}{|c|c|c|c|c|c|c|}
\hline Country & Firm name & F1 & F2 & F3 & F4 & F5 \\
\hline GB & Pearson Education Limited & 54 & 97 & 78 & 91 & 59 \\
\hline GB & Phaidon Press Limited & 49 & 41 & 47 & 86 & 67 \\
\hline GB & Quercus Editions Limited & 63 & 35 & 61 & 63 & 63 \\
\hline GB & Scholastic Limited & 47 & 73 & 67 & 62 & 93 \\
\hline GB & Titan Entertainment Group Limited & 33 & 45 & 44 & 98 & 51 \\
\hline GR & Express Publishing A.E.E. & 20 & 60 & 50 & 96 & 85 \\
\hline IT & Adriano Salani Editore SRL & 59 & 30 & 38 & 52 & 55 \\
\hline IT & $\begin{array}{l}\text { Casa Editrice Libraria Ulrico Hoepli SOC PER Azioni E PIU } \\
\text { Breve Mente Hoepli SPA }\end{array}$ & 28 & 57 & 14 & 69 & 75 \\
\hline IT & Ciscra S.P.A. & 50 & 50 & 54 & 74 & 35 \\
\hline IT & Edizioni L Informatore Agrario SRL In Breve Edia & 7 & 9 & 59 & 78 & 26 \\
\hline IT & $\begin{array}{l}\text { Edizioni Piemme SPA Siglabile In Piemme SPA Potra Assume } \\
\text { RE IL Marchio Piemme }\end{array}$ & 51 & 44 & 51 & 84 & 84 \\
\hline IT & $\begin{array}{l}\text { Istituto Della Enciclopedia Italiana Fondata DA Giovanni } \\
\text { Treccani Societa' PER Azioni }\end{array}$ & 12 & 58 & 4 & 61 & 62 \\
\hline IT & Skira Editore SPA & 15 & 46 & 3 & 68 & 53 \\
\hline SE & Aktiebolaget Svensk Byggtjänst & 76 & 34 & 13 & 76 & 74 \\
\hline SE & Skl Kommentus AB & 4 & 63 & 41 & 48 & 42 \\
\hline SE & Studentlitteratur Aktiebolag & 59 & 24 & 71 & 89 & 11 \\
\hline
\end{tabular}

Source: Own elaboration.

Table A4

Cluster 3: Firms grouped by country and corresponding percentiles in each factor

\begin{tabular}{clccccc}
\hline Country & Firm name & F1 & F2 & F3 & F4 & F5 \\
\hline $\mathrm{DE}$ & EBSCO Information Services GmbH & 7 & 75 & 58 & 15 & 96 \\
$\mathrm{DE}$ & Springer-Verlag GmbH & 13 & 95 & 90 & 4 & 100 \\
\hline $\mathrm{FR}$ & Editions Soleil & 11 & 10 & 98 & 2 & 94 \\
\hline $\mathrm{GB}$ & Quarto Publishing PLC & 31 & 88 & 42 & 6 & 98 \\
\hline $\mathrm{IT}$ & EMI Music Publishing Italia SRL & 16 & 38 & 98 & 19 & 99 \\
\hline
\end{tabular}

Source: Own elaboration.

Table A5

Cluster 4: Firms grouped by country and corresponding percentiles in each factor

\begin{tabular}{clccccc}
\hline Country & Firm name & F1 & F2 & F3 & F4 & F5 \\
\hline BE & Dupuis Logistic Services & 87 & 47 & 5 & 9 & 22 \\
BE & Groupe Larcier & 9 & 29 & 88 & 5 & 9 \\
BE & Indicator & 35 & 15 & 89 & 53 & 2 \\
BE & Societe De Distribution DU Livre Caravelle & 2 & 53 & 80 & 7 & 30 \\
BE & Uitgeverij Lannoo & 25 & 80 & 17 & 38 & 45 \\
\hline CZ & Albatros Media, a.s. & 24 & 26 & 85 & 30 & 15 \\
\hline DE & Mayr Miesbach GmbH & 58 & 80 & 52 & 3 & 72 \\
DE & Otto Harrassowitz GmbH \& Co. KG Buchhdlg u. Verlag & 80 & 85 & 8 & 22 & 11 \\
DE & TASCHEN GmbH & 41 & 64 & 22 & 50 & 33 \\
DE & Walter de Gruyter GmbH & 50 & 76 & 59 & 15 & 23 \\
\hline ES & Círculo De Lectores SA & 30 & 84 & 39 & 29 & 7 \\
ES & Comercial Grupo Anaya SA & 81 & 89 & 11 & 28 & 46 \\
ES & Ediciones B SA & 93 & 20 & 45 & 7 & 1 \\
ES & Editorial Planeta SA & 26 & 92 & 64 & 57 & 3 \\
\hline FI & Werner Söderström Osakeyhtiö & 2 & 46 & 67 & 42 & 24 \\
\hline FR & Bragelonne & 61 & 52 & 19 & 17 & 69 \\
FR & Gallimard Jeunesse & 90 & 66 & 15 & 11 & 39 \\
\hline
\end{tabular}


Table A5 (Continue)

Cluster 4: Firms grouped by country and corresponding percentiles in each factor

\begin{tabular}{|c|c|c|c|c|c|c|}
\hline Country & Firm name & F1 & F2 & F3 & F4 & F5 \\
\hline FR & Hugo \& CIE & 64 & 63 & 23 & 8 & 88 \\
\hline FR & Librairie Artheme Fayard & 85 & 81 & 11 & 2 & 85 \\
\hline FR & Presses Universitaires De France & 17 & 39 & 16 & 31 & 19 \\
\hline FR & Societe DES Editions Grasset ET Fasquelle & 44 & 71 & 9 & 11 & 80 \\
\hline GB & Egmont UK Limited & 69 & 82 & 36 & 13 & 38 \\
\hline GB & Igloo Books Group Holdings Limited & 93 & 31 & 25 & 28 & 20 \\
\hline GB & Make Believe Ideas Ltd & 95 & 27 & 12 & 20 & 24 \\
\hline GB & Osprey Publishing Limited & 28 & 36 & 26 & 45 & 50 \\
\hline GB & Springer Science + Business Media UK Limited & 6 & 72 & 1 & 33 & 52 \\
\hline GB & The Templar Company Limited & 46 & 43 & 28 & 24 & 16 \\
\hline GB & Wolters Kluwer (UK) Limited & 57 & 89 & 76 & 21 & 41 \\
\hline IT & De Agostini Scuola SPA & 67 & 61 & 79 & 27 & 6 \\
\hline IT & Edizioni Centro Studi Erickson S.P.A. & 29 & 17 & 81 & 46 & 21 \\
\hline IT & Gius. Laterza E Figli S.P.A. & 23 & 54 & 24 & 18 & 37 \\
\hline IT & Gruppo Edicart SRL & 38 & 33 & 33 & 41 & 28 \\
\hline IT & Gruppo Editoriale Zanardi S.R.L. & 8 & 74 & 74 & 1 & 10 \\
\hline IT & $\begin{array}{l}\text { Guido Veneziani Editore S.P.A. (IN Forma Abbreviata GVE } \\
\text { S.P.A.) }\end{array}$ & 53 & 85 & 33 & 25 & 14 \\
\hline IT & GUT Edizioni S.P.A. & 1 & 54 & 65 & 16 & 20 \\
\hline IT & Newton Compton Editori SRL & 65 & 48 & 35 & 26 & 79 \\
\hline IT & Raffaello Libri S.R.L. & 63 & 18 & 56 & 54 & 29 \\
\hline IT & Societa' Editrice IL Mulino - S.P.A. & 37 & 56 & 32 & 12 & 65 \\
\hline IT & Touring Editore S.R.L. & 15 & 28 & 57 & 37 & 66 \\
\hline $\mathrm{PL}$ & International Masters Publishers Sp. z o.o. & 77 & 42 & 18 & 10 & 25 \\
\hline $\mathrm{PL}$ & WYDAWNICTWO C.H. BECK Sp. z o.o. & 73 & 37 & 28 & 46 & 40 \\
\hline PT & Leya, S.A. & 43 & 87 & 73 & 20 & 12 \\
\hline SE & Lokaldelen i Sverige $A B$ & 85 & 59 & 20 & 34 & 8 \\
\hline SE & Norstedts Förlagsgrupp AB & 48 & 68 & 21 & 44 & 15 \\
\hline SK & Ikar, a.s. & 19 & 40 & 10 & 41 & 34 \\
\hline
\end{tabular}

Source: Own elaboration.

Table A6

Cluster 5: Firms grouped by country and corresponding percentiles in each factor

\begin{tabular}{clccccc}
\hline Country & \multicolumn{1}{c}{ Firm name } & F1 & F2 & F3 & F4 & F5 \\
\hline BE & Uitgeverij Averbode - Editions Averbode & 78 & 20 & 62 & 51 & 58 \\
BE & Wolters Kluwer Belgium & 72 & 93 & 89 & 23 & 78 \\
\hline ES & Espasa Libros SL & 74 & 3 & 94 & 72 & 41 \\
ES & Signo Editores J M SL & 39 & 79 & 92 & 92 & 54 \\
\hline FI & Sanoma Pro Oy & 68 & 15 & 91 & 67 & 7 \\
\hline FR & Editions Dalloz & 84 & 72 & 76 & 49 & 36 \\
FR & Editions Jean-Claude Lattes & 92 & 37 & 85 & 65 & 93 \\
FR & Harlequin & 89 & 67 & 37 & 24 & 91 \\
FR & LES Editions Hatier & 88 & 86 & 55 & 54 & 89 \\
FR & Pika Edition & 94 & 33 & 30 & 14 & 92 \\
\hline GB & Blackwell Publishing Limited & 89 & 93 & 93 & 36 & 2 \\
GB & Little, Brown Book Group Limited & 76 & 83 & 82 & 89 & 76 \\
GB & The Random House Group Limited & 83 & 96 & 87 & 67 & 56 \\
\hline IE & Thomson Reuters (Professional) Ireland Limited & 14 & 1 & 100 & 87 & 4 \\
\hline IT & Garzanti Libri S.R.L. & 62 & 14 & 75 & 71 & 76 \\
IT & Giunti Scuola SRL & 79 & 23 & 83 & 59 & 61 \\
IT & Harlequin Mondadori SPA & 98 & 6 & 63 & 47 & 80 \\
IT & Ipsoa Francis Lefebvre SRL & 99 & 2 & 96 & 80 & 95 \\
IT & Longanesi \& C. Societa' PER Azioni & 70 & 11 & 77 & 81 & 86 \\
\hline
\end{tabular}


Table A6 (Continue)

Cluster 5: Firms grouped by country and corresponding percentiles in each factor

\begin{tabular}{|c|c|c|c|c|c|c|}
\hline Country & Firm name & F1 & F2 & F3 & F4 & F5 \\
\hline IT & $\begin{array}{l}\text { Panini Societa' PER Azioni O In Forma Abbreviata Panini } \\
\text { S.P.A. }\end{array}$ & 52 & 94 & 97 & 43 & 31 \\
\hline IT & Sellerio Editore SRL & 80 & 4 & 95 & 58 & 71 \\
\hline IT & Tea Tascabili Degli Editori Associati SPA & 82 & 7 & 80 & 75 & 67 \\
\hline IT & Warner Chappell Music Italiana SRL & 32 & 2 & 99 & 37 & 13 \\
\hline LU & Editus Luxembourg SA & 86 & 5 & 93 & 66 & 47 \\
\hline SE & Brandskyddsföreningens Service $A B$ & 98 & 12 & 7 & 35 & 50 \\
\hline SE & Gleerups Utbildning Aktiebolag & 100 & 8 & 24 & 59 & 44 \\
\hline SE & Norstedts Juridik Aktiebolag & 96 & 59 & 66 & 33 & 27 \\
\hline SE & Pearson Sweden AB & 42 & 7 & 86 & 76 & 83 \\
\hline SE & Sanoma Utbildning Aktiebolag & 91 & 22 & 72 & 79 & 59 \\
\hline SE & Sis Förlag Aktiebolag & 97 & 19 & 7 & 40 & 54 \\
\hline
\end{tabular}

Source: Own elaboration. 